\title{
Effect of administration of ultra-corn with bivalent Foot and Mouth disease oil vaccine in calves
}

\author{
Eman Mahmoud Mohamed ${ }^{1}$, Ehab El-Sayed Ibrahim $^{2}$ and Fatma Sayed Mohamed ${ }^{2}$ \\ 1. Central Laboratory for evaluation of veterinary biologics, Abbasia, Cairo, Egypt; \\ 2. Veterinary Serum and Vaccine Research Institute, P.O.Box:131, Abbasia, Cairo, Egypt \\ Corresponding author: Ehab El-Sayed Ibrahim, Fax: (202) 23428321, email:ehabelsayed@hotmail.com \\ Received: 26-01-2013, Revised: 14-02-2013, Accepted: 20-02-2013, Published online: 16-05-2013
}

\section{How to cite this article:}

Mohamed EM, Ibrahim EE and Mohamed FS (2013) Effect of administration of ultracorn with bivalent Foot and Mouth disease oil vaccine in calves, Vet World 6(8): 486-492, doi:10.5455/vetworld.2013.486-492

\begin{abstract}
Aim: The present work was established in order to investigate the effect of ultra-corn administration on the immune response of vaccinated calves with FMD bivalent oil vaccine.

Material and Methods: Forty calves; at a private farm in EL-Fayoum Governorate (Locality A); were divided into 4 groups where the first group was vaccinated with the locally produced FMD bivalent oil vaccine alone while the $2^{\text {nd }}, 3^{\text {rd }}$ and $4^{\text {th }}$ group were vaccinated with the same vaccine simultaneously with the inoculation of $1,1.5$ and $2 \mathrm{~mL} / 100 \mathrm{~kg}$ body weight of ultra-corn respectively to estimate the antibody titer, the suitable dose and effect of ultra-corn as immunostimulant using SNT and ELISA. Also after that used the effective and lowest dose of ultra-corn simultaneously with the vaccine in comparison with the vaccine alone by using 26 calves (Locality B) to study the efficacy of ultra-corn simultaneously with vaccine and the vaccine alone via challenge test using the virulent FMDV serotype A,O.

Results: Tested serum samples obtained on week intervals post vaccination of all calve groups were subjected for estimation of induced FMD antibodies type A and $\mathrm{O}$ using serum neutralization test (SNT) and enzyme linked immune sorbent assay (ELISA). Both tests indicate that $1.5 \mathrm{~mL}, 2 \mathrm{~mL}$ of ultra-corn enhanced the immune response of vaccinated calves exhibiting higher and longer immunity than those received the vaccine alone. In addition 26 calves housed under restrict hygienic measures at Veterinary Serum and Vaccine Research Institute, were divided into 4 groups where group-1 of 10 calves were vaccinated with the bivalent FMD vaccine alone and group-2 was vaccinated with the same vaccine simultaneously with $1.5 \mathrm{~mL}$ of ultra-corn while group 3 and 4 were kept as control for the challenge test. On the $4^{\text {th }}$ week post vaccination group 1,2 of these animals was subdivided into 2 subgroups where the challenge test was carried out against type $\mathrm{A}$ in a subgroup and $\mathrm{O}$ in other subgroup. SNT and ELISA showed similar results obtained from the vaccinated farm animals and challenge test via inoculation of virulent virus of FMD serotype $\mathrm{A}, \mathrm{O}$ indicated that animals received ultra-corn showed $100 \%$ protection against both types of FMD virus while those did not receive ultra-corn showed $80 \%$ protection (vaccine alone).
\end{abstract}

Conclusion: So it could be concluded that ultra-corn has a potentiate effect on the immunogenicity of bivalent oil FMD vaccine providing high immune levels of long duration.

Keywords: bivalent, calves, FMD, immune response, serotype, vaccine

\section{Introduction}

Foot-and-mouth disease (FMD) is considered one of the most serious viral infections in livestock, because of its rapid transmission over a range of animal species. As FMD is still endemic in large regions of the world, it is a highly infectious disease of ungulates primarily cattle, sheep, goats and pigs. It also affects wild animals such as buffaloes and deer [1]. Foot-andmouth disease virus (FMDV) is the etiologic agent of the diseases that can affect cloven-hoofed livestock. Infection with FMDV characterized by fever, lameness and vesicular lesions on the feet, tongue, snout and teats, with high morbidity but low mortality [2]. There are seven types of FMD virus (FMDV) have been identified as; $\mathrm{O}, \mathrm{A}, \mathrm{C}, \mathrm{SAT}_{1}, \mathrm{SAT}_{2}, \mathrm{SAT}_{3}$ and Asial [3] and [4].

It was stated that vaccination against infectious

This article is an open access article licensed under the terms of the Creative Commons Attribution License (http://creativecommons. org/licenses/by/2.0) which permits unrestricted use, distribution and reproduction in any medium, provided the work is properly cited. diseases is the corner stone to eradicate or even to control such diseases. Many trials were carried out in order to improve the potency of FMD inactivated vaccine using different adjuvant aiming to potentiate its immunogenicity and to increase the duration of induced immunity in vaccinated animals [5].

Montanide ISA206 oil adjuvant quadric-valent FMD vaccine elicited a better immune response at any time than aluminum hydroxide gel vaccine, and this response was developed quicker. The animals maintained their neutralizing antibody titers at $>3 \log _{10}$ for the duration of the trial (90 days) [6]. The mean protective serum antibody titers against FMD in calves vaccinated with double oil emulsion (Montanide ISA 206) evaluated by Enzyme Linked Immunosorbent Assay (ELISA) and Serum Nutralization Test (SNT) was started at the $3^{\text {rd }}$ week post vaccination (WPV) reached the highest level at the $10^{\text {th }} \mathrm{WPV}$ and continued with the protective level till the $32 \mathrm{WPV}$ then started to decline under the protective level for both FMD virus types $\mathrm{O}$ and $\mathrm{A}[7]$. 
The immune response of vaccinated goats with alhydargel and double oil emulsion Montanide ISA 206 vaccines persisted for 20 and 36 weeks post challenge, respectively [8]. Also $[9,10]$ found that such vaccine induced long lasting immunity than that with Alhydragel adjuvant.

The immune response estimated by using SNT and ELISA revealed that the antibody titers of the FMD vaccines with ultra-corn in calves appeared earlier and higher at the first six weeks post vaccination than that of FMD gel vaccine alone and the calves persisted for 16 weeks post vaccination for both [11].

The vaccinated calves with bivalent FMD ISA 206 inactivated oil vaccine should be revaccinated on the 36 weeks post vaccination to avoid the decline of the protective immune levels to the non-protective values [12].

The study was aim to determine the effect of ultracorn as an immune modulator to the locally produced bivalent FMD oil vaccine on the immune status of vaccinated calves.

\section{Materials and Methods}

Animals: The present work was subjected on 66 apparently healthy calves of 6-8 months of age from two localities and free from FMD type $\mathrm{O}_{1} /$ Aga/Egy/93 and $\mathrm{A} / \mathrm{Egy} / 1 / 2006$ antibodies as screened by serum neutralization test and indirect ELISA.

*Locality (A):

Includes 40 calves at private farm at El-Fayoum Governorate divided into 4 groups (10 calves/ group) where group (1) was vaccinated with the bivalent oil FMD vaccine using a dose of $2 \mathrm{~mL} /$ animal inoculated subcutaneously while group 2, 3 and 4 were inoculated with $1,1.5$ and $2 \mathrm{~mL} / 100 \mathrm{~kg}$ body weight of ultra-corn simultaneously with the same dose of FMD vaccine. *Locality (B):

Includes 26 calves housed in Veterinary Serum and Vaccine Research Institute, Abassia, Cairo. These animals were divided into 4 groups where each of group 1 and 2 includes 10 calves then divided equally to be challenged with FMDV serotype A,O, while each of group 3 and 4 contains 3 calves. Group (1) was vaccinated with FMD bivalent vaccine only and group (2) was inoculated with $1.5 \mathrm{~mL}$ of ultra-corn $/ 100 \mathrm{Kg}$ body weight animal simultaneously with FMD vaccine while group 3 and 4 were kept without vaccination as positive control challenged with FMDV serotype A,O.

Ethical approval: The experiment was as per the protocol of Institutional Animal Ethics Committee, the authors had taken permission of animal owners of private farm.

Viruses: Locally isolated FMDV type $\mathrm{O}_{1} / \mathrm{Aga} / \mathrm{EGY} / 93$ with titter of $10^{9} \mathrm{TCID}_{50} / \mathrm{mL}$ and type $\mathrm{A} / \mathrm{EGY} / 1 / 2006$ with titer $10^{9} \mathrm{TCID}_{50} / \mathrm{mL}$ were supplied by Foot and Mouth Vaccine Research Department (FMDRD), Veterinary Serum and Vaccine Research Institute, Abbasia, Cairo. These viruses were used for challenge test.
Cell culture: Baby Hamster kidney cell line (BHK21) Clone 13 maintained in FMD Department, Abbasia, Cairo using Eagl's medium with 8-10\% sterile bovine serum as described by [13], was used for application of serum neutralization test.

Vaccine: Local produced inactivated bivalent FMD vaccine including type $\left(\mathrm{O}_{1} / 93 / \mathrm{Aga}\right)$ and type $(\mathrm{A} /$ Egypt/2006) adjuvanted with Montanide ISA 206 oil was supplied by Veterinary Serum and Vaccine Research Institute to be used for vaccination of calves [14].

\section{Ultra-corn:}

- It is a product of Virbac Company, France.

- It is consisted of Corynebacterium cutis lysate (destroyed and lysed by using ultrasonic device) as $20 \mathrm{mg} / \mathrm{mL}$ of the product.

- $\quad$ Ultra-corn is used for prevention of diarrhoea and pneumonia infections of newborn animals when administered to the dams at the late pregnancy, prevention of placental infections in case of retained placenta when administered during late pregnancy and used as preventive measures or supportive therapy in case of respiratory or digestive diseases due to contagious bacterial, viral, and other pathogens.

- Storage conditions : store in the refrigerator (2$\left.6^{\circ} \mathrm{C}\right)$.

Vaccination: All vaccinated calves was vaccinated using inactivated bivalent $(\mathrm{A}, \mathrm{O})$ Foot and Mouth Disease Montanide ISA206 oil vaccine with dose $2 \mathrm{~mL} /$ animal subcutaneously.

Challenge test: All vaccinated calves and positive control were inoculated with the challenged FMDV either serotype $\mathrm{A}$ or $\mathrm{O}$ with titer $10^{4} \mathrm{BID}_{50}$ at the base on the tongue. All challenged animals were kept under daily observation and clinically examined for 1 week post infection (WPI), where body temperature and lesions on the gum and oral mucosa as well as foot pad were recorded.

Serum neutralization test (SNT): It was performed using the micro titer technique as described by [15] to evaluate the levels of induced FMD antibodies in experimentally vaccinated calves.

Indirect enzyme linked immune sorbent assay (iELISA): Indirect ELISA was carried out according to [16] to follow up the immune response in animals.

\section{Results and Discussion}

Foot and Mouth disease (FMD) is one of the most wide spread diseases affecting cloven footed animals of detrimental effects on meat and milk production, rather than convalescent animals became carriers and source of infection [17]. In countries where the disease is endemic, drastic measures of eradication are not always economically feasible. Control is based on a modified system of vaccination and quarantine, using vaccines specific for the type and subtype of the viruses involved. Vaccines containing one or more immune 
Table-1. Mean FMD serum neutralizing antibody titers in calves vaccinated with bivalent FMD with ultra-corn simultaneous (locality A)

\begin{tabular}{|c|c|c|c|c|c|c|c|c|}
\hline \multirow[t]{3}{*}{ WPV } & \multirow{2}{*}{\multicolumn{2}{|c|}{$\begin{array}{l}\text { calves receiving the } \\
\text { vaccine alone }\end{array}$}} & \multicolumn{6}{|c|}{$\begin{array}{l}\text { Mean FMD serum neutralizing antibody titers }\left(\log _{10} / \mathrm{mL}\right) \text { in calves group vaccinated with } \\
\text { bivalent FMD vaccine simultaneously with }\end{array}$} \\
\hline & & & \multicolumn{2}{|c|}{$\begin{array}{l}1 \mathrm{~mL} \text { ultra-corn } / 100 \mathrm{~kg} \\
\text { body weight }\end{array}$} & \multicolumn{2}{|c|}{$\begin{array}{l}1.5 \mathrm{~mL} \text { ultra-corn } / 100 \mathrm{~kg} \\
\text { body weight }\end{array}$} & \multicolumn{2}{|c|}{$\begin{array}{l}2 \mathrm{~mL} \text { ultra-corn } / 100 \mathrm{~kg} \\
\text { body weight }\end{array}$} \\
\hline & $A^{*}$ & $0^{* *}$ & A & 0 & A & 0 & A & 0 \\
\hline 0 & $0.2^{* \star *}$ & 0.5 & 0.25 & 0.4 & 0.27 & 0.45 & 0.15 & 0.42 \\
\hline 2 & 1.1 & 1.32 & 1.5 & 1.63 & 1.5 & 1.9 & 1.75 & 1.85 \\
\hline 4 & 1.55 & 1.7 & 1.6 & 1.8 & 1.88 & 2.3 & 1.88 & 2.35 \\
\hline 6 & 1.73 & 1.83 & 1.8 & 1.95 & 1.95 & 2.3 & 2 & 2.35 \\
\hline 8 & 1.85 & 1.9 & 1.95 & 2.05 & 2.15 & 2.35 & 2.25 & 2.4 \\
\hline 12 & 1.95 & 2.22 & 2.1 & 2.3 & 2.3 & 2.5 & 2.35 & 2.5 \\
\hline 16 & 2.2 & 2.35 & 2.3 & 2.55 & 2.53 & 2.7 & 2.6 & 2.75 \\
\hline 20 & 2 & 2.1 & 2.1 & 2.3 & 2.4 & 2.55 & 2.45 & 2.6 \\
\hline 24 & 1.82 & 1.9 & 1.95 & 2.05 & 2.25 & 2.3 & 2.28 & 2.4 \\
\hline 28 & 1.71 & 1.8 & 1.8 & 1.95 & 2 & 2.15 & 2.05 & 2.2 \\
\hline 32 & 1.6 & 1.6 & 1.7 & 1.8 & 1.85 & 1.95 & 1.9 & 2.05 \\
\hline 36 & 1.4 & 1.5 & 1.55 & 1.65 & 1.71 & 1.83 & 1.79 & 1.9 \\
\hline 40 & 1.2 & 1.3 & 1.35 & 1.52 & 1.5 & 1.65 & 1.55 & 1.7 \\
\hline 44 & 0.9 & 1 & 1.2 & 1.3 & 1.35 & 1.5 & 1.35 & 1.55 \\
\hline
\end{tabular}

WPV: Weeks post vaccination, *A: FMDV serotype A, **O: FMDV serotype $0, * * *$ Antibody titers expressed in log $_{10}$. The recommended protective levels of FMD antibody titers are $1.5 \log _{10}$ for SNT for both of type A and O as estimated by SNT [4]

Table-2. Mean FMD ELISA antibody titer of calves vaccinated with bivalent FMD with ultra-corn simultaneous (locality A)

\begin{tabular}{|c|c|c|c|c|c|c|c|c|}
\hline \multirow[t]{3}{*}{ WPV } & \multicolumn{2}{|c|}{$\begin{array}{l}\text { calves receiving the } \\
\text { vaccine alone }\end{array}$} & \multicolumn{6}{|c|}{$\begin{array}{c}\text { Mean FMD ELISA titers }\left(\log _{10} / \mathrm{mL}\right) \text { in calves group vaccinated with bivalent FMD } \\
\text { vaccine simultaneously with }\end{array}$} \\
\hline & \multirow[b]{2}{*}{$A^{*}$} & \multirow[b]{2}{*}{$0^{* *}$} & \multicolumn{2}{|c|}{$\begin{array}{l}1 \mathrm{~mL} \text { ultra-corn } / 100 \mathrm{~kg} \\
\text { body weight }\end{array}$} & \multicolumn{2}{|c|}{$\begin{array}{l}1.5 \mathrm{~mL} \text { ultra-corn/100kg } \\
\text { body weight }\end{array}$} & \multicolumn{2}{|c|}{$\begin{array}{l}2 \mathrm{~mL} \text { ultra-corn } / 100 \mathrm{~kg} \\
\text { body weight }\end{array}$} \\
\hline & & & A & 0 & A & 0 & A & 0 \\
\hline 0 & $0.36^{\star * *}$ & 0.65 & 0.45 & 0.56 & 0.47 & 0.68 & 0.36 & 0.63 \\
\hline 2 & 1.28 & 1.52 & 1.76 & 1.84 & 1.79 & 2.09 & 2.01 & 2.2 \\
\hline 4 & 1.71 & 1.87 & 1.78 & 1.96 & 2.13 & 2.56 & 2.12 & 2.6 \\
\hline 6 & 1.9 & 2.01 & 2.03 & 2.16 & 2.22 & 2.58 & 2.26 & 2.61 \\
\hline 8 & 2 & 2.06 & 2.14 & 2.25 & 2.39 & 2.6 & 2.55 & 2.69 \\
\hline 12 & 2.11 & 2.39 & 2.33 & 2.57 & 2.58 & 2.79 & 2.6 & 2.71 \\
\hline 16 & 2.35 & 2.52 & 2.51 & 2.79 & 2.8 & 2.98 & 2.88 & 3.02 \\
\hline 20 & 2.15 & 2.27 & 2.31 & 2.54 & 2.66 & 2.83 & 2.72 & 2.89 \\
\hline 24 & 1.97 & 1.98 & 2.09 & 2.24 & 2.49 & 2.58 & 2.55 & 2.69 \\
\hline 28 & 1.87 & 1.95 & 2 & 2.15 & 2.27 & 2.44 & 2.34 & 2.47 \\
\hline 32 & 1.75 & 1.76 & 1.9 & 2.03 & 2.06 & 2.09 & 2.17 & 2.34 \\
\hline 36 & 1.55 & 1.56 & 1.8 & 1.91 & 2 & 2.04 & 2.06 & 2.16 \\
\hline 40 & 1.36 & 1.45 & 1.59 & 1.78 & 1.77 & 1.94 & 1.82 & 1.97 \\
\hline 44 & 1.06 & 1.16 & 1.44 & 1.55 & 1.64 & 1.79 & 1.65 & 1.85 \\
\hline
\end{tabular}

*A: FMDV serotype $A, * * 0$ : FMDV serotype $0, * * *$ Antibody titers expressed in $\log _{10}$

The recommended protective levels of FMD antibody titers are $1.9 \log _{10}$ for ELISA for both of type A and O as estimated by ELISA [4]

types of the virus are produced in several countries. Gel adjuvant vaccine is often less successful than vaccination of cattle and sheep by recently oil-adjuvant vaccines which have been used with excellent results. If the latter system is used, annual revaccination is essential [18]. The progress in vaccine production is directed towards the selection of the proper adjuvant that can elaborate high and long lasting immunity. The vaccine efficacy is measured by the level and duration of protective immune response and the proportion of vaccinated animals which demonstrate immunity (resist challenge) [19].

As obtained from the present work, Table-1 showed that vaccinated calves with bivalent FMD oil vaccine alone and smiltaniously inject with either 1, 1.5 or $2 \mathrm{~mL}$ of ultra-corn exhibited specific neutralizing antibody against type $\mathrm{A}$ and type $\mathrm{O}$ started from the $2^{\text {nd }}$ WPV. On the use of FMD bivalent vaccine alone; it was noticed that the specific FMD neutralizing antibody titers reached a protective level starting from the $4^{\text {th }}$
WPV to record peak titers by the $16^{\text {th }}$ WPV then began to decline gradually by the $20^{\text {th }} \mathrm{WPV}$ till $36^{\text {th }} \mathrm{WPV}$ for type $\mathrm{O}$ then became unprotected. On the other side the mean neutralizing antibody titers against type (A) in calves vaccinated with bivalent oil FMD vaccine simultaneously with $1 \mathrm{~mL}$ ultra-corn reached the protective level by the $2^{\text {nd }}$ WPV till $36^{\text {th }}$ WPV then became unprotected level . Also mean neutralizing antibody titers against type $(\mathrm{O})$ in such calves showed the same manner but still protective till the $40^{\text {th }}$. The mean neutralizing antibody titers against type (A) in calves vaccinated with bivalent oil FMD vaccine simultaneously with $1.5 \mathrm{~mL}$ ultra-corn became protective by the $2^{\text {nd }}$ WPV till $40^{\text {th }}$ WPV where they became unprotected by the $44^{\text {th }}$ WPV. Similarly, mean neutralizing antibody titers against type $(\mathrm{O})$ in the same calves showed the same behavior indicating that type $\mathrm{O}$ antibodies were higher than those of type A and lasts for 44 WPV. In calves vaccinated with bivalent oil FMD vaccine simultaneously with $2 \mathrm{~mL}$ ultra-corn, FMD 
Table-3. Mean FMD serum neutralizing antibody titers in calves vaccinated with bivalent FMD and $1.5 \mathrm{~mL}$ ultra-corn/100kg body weight simultaneously (Locality B)

\begin{tabular}{|c|c|c|c|c|c|c|c|c|c|c|c|c|}
\hline \multirow{3}{*}{$\begin{array}{l}\text { Animals } \\
\text { No. }\end{array}$} & \multirow[t]{3}{*}{ Treatment of animals } & \multicolumn{10}{|c|}{ Mean FMD serum neutralizing antibody titer $\left(\log _{10} / \mathrm{mL}\right)$} & \multirow[t]{3}{*}{ challenge } \\
\hline & & \multicolumn{2}{|c|}{0 WPV* $^{*}$} & \multicolumn{2}{|c|}{1 WPV } & \multicolumn{2}{|c|}{ 2WPV } & \multicolumn{2}{|c|}{ 3WPV } & \multicolumn{2}{|c|}{ 4WPV } & \\
\hline & & $A^{* *}$ & $\mathbf{O}^{* * *}$ & A & 0 & A & 0 & A & 0 & A & 0 & \\
\hline 1 & vaccinated with & 0.15 & - & 0.6 & - & 0.9 & - & 1.2 & - & 1.35 & - & $A$ \\
\hline 2 & FMD bivalent & 0.3 & - & 0.75 & - & 1.2 & - & 1.35 & - & 1.65 & - & A \\
\hline 3 & oil vaccine alone & 0.3 & - & 0.6 & - & 0.9 & - & 1.35 & - & 1.5 & - & $A$ \\
\hline 4 & & 0.15 & - & 0.9 & - & 1.05 & - & 1.2 & - & 1.5 & - & $A$ \\
\hline 5 & & 0.3 & - & 0.9 & - & 1.35 & - & 1.5 & - & 1.65 & - & $A$ \\
\hline 6 & & - & 0.45 & - & 0.9 & - & 1.35 & - & 1.65 & - & 1.8 & $\mathrm{O}$ \\
\hline 7 & & - & 0.3 & - & 0.9 & - & 1.05 & - & 1.2 & - & 1.8 & $\mathrm{O}$ \\
\hline 8 & & - & 0.6 & - & 1.05 & - & 1.5 & - & 1.8 & - & 2.1 & $\mathrm{O}$ \\
\hline 9 & & - & 0.3 & - & 0.9 & - & 1.05 & - & 1.2 & - & 1.35 & $\mathrm{O}$ \\
\hline \multirow[t]{2}{*}{10} & & - & 0.45 & - & 1.05 & - & 1.35 & - & 1.5 & - & 1.8 & $\mathrm{O}$ \\
\hline & Mean & 0.24 & 0.42 & 0.75 & 0.96 & 1.08 & 1.26 & 1.32 & 1.47 & 1.53 & 1.63 & - \\
\hline 11 & vaccinated with & 0.3 & - & 1.2 & - & 1.5 & - & 1.65 & - & 1.95 & - & $A$ \\
\hline 12 & FMD bivalent oil & 0.3 & - & 1.2 & - & 1.35 & - & 1.65 & - & 1.8 & - & $A$ \\
\hline 13 & vaccine and $1.5 \mathrm{~cm}$ & 0.3 & - & 1.2 & - & 1.35 & - & 1.8 & - & 1.95 & - & $A$ \\
\hline 14 & of ultra corn & 0.3 & - & 1.35 & - & 1.5 & - & 1.5 & - & 1.8 & - & $A$ \\
\hline 15 & simultaneously & 0.3 & - & 1.2 & - & 1.5 & - & 1.8 & - & 1.95 & - & $A$ \\
\hline 16 & & - & 0.45 & - & 1.35 & - & 1.65 & - & 1.8 & - & 2.1 & $\mathrm{O}$ \\
\hline 17 & & - & 0.3 & - & 1.2 & - & 1.5 & - & 1.95 & - & 1.95 & $\mathrm{O}$ \\
\hline 18 & & - & 0.45 & - & 1.35 & - & 1.65 & - & 1.8 & - & 1.95 & $\mathrm{O}$ \\
\hline 19 & & - & 0.3 & - & 1.35 & - & 1.65 & - & 1.8 & - & 2.1 & $\mathrm{O}$ \\
\hline \multirow[t]{2}{*}{20} & & - & 0.45 & - & 1.2 & - & 1.5 & - & 1.65 & - & 1.95 & $\mathrm{O}$ \\
\hline & Mean & 0.3 & 0.47 & 1.24 & 1.55 & 1.43 & 1.91 & 1.69 & 2.16 & 1.88 & 2.41 & - \\
\hline 21 & control positive A & 0.3 & - & 0.3 & - & 0.3 & - & 0.3 & - & 0.3 & - & $A$ \\
\hline 22 & & 0.3 & - & 0.3 & - & 0.3 & - & 0.3 & - & 0.3 & - & A \\
\hline 23 & & 0.3 & - & 0.3 & - & 0.3 & - & 0.3 & - & 0.3 & - & A \\
\hline 24 & control positive O & - & 0.3 & - & 0.3 & & 0.3 & - & 0.3 & - & 0.3 & $\mathrm{O}$ \\
\hline 25 & & - & 0.3 & - & 0.3 & & 0.3 & - & 0.3 & - & 0.3 & $\mathrm{O}$ \\
\hline 26 & & - & 0.3 & - & 0.3 & & 0.3 & - & 0.3 & - & 0.3 & $\mathrm{O}$ \\
\hline
\end{tabular}

*WPV: Weeks post vaccination, **A: FMDV serotype A, ***O: FMDV serotype 0

The recommended protective levels of FMD antibody titers are $1.5 \log _{10}$ for SNT for both of type A and O as estimated by SNT [4]

type A neutralizing antibodies became protective starting from the $2^{\text {nd }}$ WPV till the $40^{\text {th }}$ WPV but the means neutralizing antibody against type $(\mathrm{O})$ in calves vaccinated by the same manner became protective by the $2^{\text {nd }} \mathrm{WPV}$ till the $44^{\text {th }} \mathrm{WPV}$ then became unprotected level. Also the results of ELISA came parallel to those of SNT as shown in Table-2. These results agree with those obtained by $[7,9,10,20,21]$ they reported that the mean antibody titers against FMD vaccine strain $\mathrm{O}_{1} / 3 / 93$ were detected in sheep sera vaccinated with Alum-hydroxide gel vaccine following one week post vaccination $\left(0.9 \log _{10}\right)$ by SNT, whereas, the mean peak titers $\left(1.9 \log _{10}\right)$ by SNT were detected by the $16^{\text {th }}$ week post vaccination. And also agree with [11] who mentioned that the immune response estimated by using SNT and ELISA revealed that the antibody titers induced by FMD vaccines with ultra-corn in calves appeared earlier and higher at the first six weeks post vaccination than those induced by FMD gel vaccine alone and persisted for 16 weeks post vaccination in calves for both types. The significant increase in the immune response in calves vaccinated with bivalent FMD oil vaccine simultaneously with ultra-corn could be attributed to the mode of action of ultra-corn as immune stimulant as explained by [22] who mentioned that killed Corynebacterium cutis stimulates the activity of both $\mathrm{T}$ and B lymphocytes which lead to increase the antibody synthesis, and [23] who found that corynaebactreium is one of the strongest inducers of lymphocytes trapping, [24] reported that the administration of ultra-corn induced marked immune potentiating effect of the immune response developed against Newcastle disease vaccine in chickens especially when given simultaneously with the vaccine.

As shown in Table- 3 and 4 , the challenge test was carried out on the 26 calves on the $4^{\text {th }} \mathrm{WPV}$, where the mean antibody against type (A) in 5 calves vaccinated with bivalent oil FMD vaccine alone started by the $1^{\text {st }}$ WPV $\left(0.75 \& 0.98 \log _{10}\right)$ to become protective at the $4^{\text {th }}$ WPV $\left(1.53 \& 1.81 \log _{10}\right)$ by SNT and ELISA respectively while those against type $(\mathrm{O})$ in other 5 calves vaccinated with bivalent oil FMD vaccine alone by $1^{\text {st }}$ WPV were $\left(0.96 \& 1.196 \log _{10}\right)$ to become protective at the $4^{\text {th }}$ WPV $\left(1.63 \& 2.01 \log _{10}\right)$ by SNT and ELISA respectively, in comparison with the means antibody against type (A) in 5 calves vaccinated with bivalent oil FMD vaccine simultaneously with $1.5 \mathrm{~mL}$ ultra-corn started by the $1^{\text {st }}$ WPV $\left(1.24 \& 1.44 \log _{10}\right)$ till become protective at the $4^{\text {th }} \mathrm{WPV}\left(1.88 \& 2.074 \log _{10}\right)$ by SNT and ELISA respectively while the mean antibody titers against type $(\mathrm{O})$ in 5 calves vaccinated with bivalent oil FMD vaccine alone started by the $1^{\text {st }}$ WPV $(1.55 \&$ $\left.1.486 \log _{10}\right)$ till become protective at $4^{\text {th }}$ WPV $(2.41 \&$ $2.22 \log _{10}$ ) by SNT and ELISA respectively. The antibody titers of control unvaccinated calves remain unprotected till 4 weeks before starting challenge test. The clinical signs described in challenged vaccinated calves after 4 WPV (Table-5) included either the 
Table-4. Mean FMD ELISA antibody titer of calves vaccinated with bivalent FMD and $1.5 \mathrm{~mL} / 100 \mathrm{~kg}$ body weight ultra-corn simultaneously (Locality B)

\begin{tabular}{|c|c|c|c|c|c|c|c|c|c|c|c|c|}
\hline \multirow{3}{*}{$\begin{array}{l}\text { Animals } \\
\text { No. }\end{array}$} & \multirow[t]{3}{*}{ Treatment of animals } & \multicolumn{10}{|c|}{ Mean FMD ELISA antibody titer $\left(\log _{10} / \mathrm{mL}\right)$} & \multirow[t]{3}{*}{ challenge } \\
\hline & & \multicolumn{2}{|c|}{0 WPV* $^{*}$} & \multicolumn{2}{|c|}{1 WPV } & \multicolumn{2}{|c|}{ 2WPV } & \multicolumn{2}{|c|}{ 3WPV } & \multicolumn{2}{|c|}{ 4WPV } & \\
\hline & & $A^{* *}$ & $\mathbf{O}^{* * *}$ & A & 0 & A & 0 & A & 0 & A & 0 & \\
\hline 1 & vaccinated with FMD & 0.3 & - & 0.75 & - & 1.06 & - & 1.35 & - & 1.51 & - & $A$ \\
\hline 2 & bivalent oil & 0.45 & - & 0.96 & - & 1.41 & - & 1.51 & - & 1.89 & - & $A$ \\
\hline 3 & vaccine alone & 0.4 & - & 0.85 & - & 1.14 & - & 1.58 & - & 1.93 & - & $A$ \\
\hline 4 & & 0.35 & - & 1.17 & - & 1.32 & - & 1.47 & - & 1.87 & - & $A$ \\
\hline 5 & & 0.54 & - & 1.17 & - & 1.63 & - & 1.77 & - & 1.85 & - & $A$ \\
\hline 6 & & - & 0.61 & - & 1.16 & - & 1.45 & - & 1.8 & - & 1.97 & $\mathrm{O}$ \\
\hline 7 & & - & 0.51 & - & 1.14 & - & 1.35 & - & 1.38 & - & 2.01 & $\mathrm{O}$ \\
\hline 8 & & - & 0.87 & - & 1.28 & - & 1.75 & - & 2.01 & - & 2.35 & $\mathrm{O}$ \\
\hline 9 & & - & 0.55 & - & 1.09 & - & 1.31 & - & 1.78 & - & 1.63 & $\mathrm{O}$ \\
\hline \multirow[t]{2}{*}{10} & & - & 0.73 & - & 1.31 & - & 1.59 & - & 1.77 & - & 2.1 & $\mathrm{O}$ \\
\hline & Mean & 0.408 & 0.654 & 0.98 & 1.196 & 1.312 & 1.49 & 1.536 & 1.748 & 1.81 & 2.012 & - \\
\hline 11 & vaccinated with FMD & 0.45 & 0 & 1.36 & 0 & 1.7 & 0 & 1.88 & 0 & 2.16 & 0 & $A$ \\
\hline 12 & bivalent oil & 0.48 & 0 & 1.35 & 0 & 1.61 & 0 & 1.91 & 0 & 1.95 & 0 & A \\
\hline 13 & vaccine and & 0.51 & 0 & 1.4 & 0 & 1.63 & 0 & 1.98 & 0 & 2.1 & 0 & $A$ \\
\hline 14 & $1.5 \mathrm{~mL}$ of ultra corn & 0.45 & 0 & 1.59 & 0 & 1.76 & 0 & 1.71 & 0 & 1.96 & 0 & $A$ \\
\hline 15 & simultaneously & 0.48 & 0 & 1.5 & 0 & 1.78 & 0 & 2.03 & 0 & 2.2 & 0 & $A$ \\
\hline 16 & & 0 & 0.69 & 0 & 1.58 & 0 & 1.81 & 0 & 1.96 & 0 & 2.26 & $\mathrm{O}$ \\
\hline 17 & & 0 & 0.46 & 0 & 1.46 & 0 & 1.68 & 0 & 2.23 & 0 & 2.12 & $\mathrm{O}$ \\
\hline 18 & & 0 & 0.66 & 0 & 1.52 & 0 & 1.85 & 0 & 2.08 & 0 & 2.15 & $\mathrm{O}$ \\
\hline 19 & & 0 & 0.56 & 0 & 1.54 & 0 & 1.84 & 0 & 2.09 & 0 & 2.36 & $\mathrm{O}$ \\
\hline \multirow[t]{2}{*}{20} & & 0 & 0.74 & 0 & 1.33 & 0 & 1.7 & 0 & 1.85 & 0 & 2.21 & $\mathrm{O}$ \\
\hline & Mean & 0.474 & 0.622 & 1.44 & 1.486 & 1.696 & 1.776 & 1.902 & 2.042 & 2.074 & 2.22 & - \\
\hline 21 & control positive A & 0.6 & - & 0.37 & - & 0.45 & - & 0.53 & - & 0.51 & - & $A$ \\
\hline 22 & & 0.5 & - & 0.41 & - & 0.43 & - & 0.59 & - & 0.53 & - & $A$ \\
\hline 23 & & 0.55 & - & 0.5 & - & 0.56 & - & 0.6 & - & 0.45 & - & $A$ \\
\hline 24 & control positive $\mathrm{O}$ & - & 0.4 & - & 0.45 & & 0.45 & - & 0.6 & - & 0.48 & 0 \\
\hline 25 & & - & 0.53 & - & 0.51 & & 0.48 & - & 0.57 & - & 0.53 & 0 \\
\hline 26 & & - & 0.43 & - & 0.51 & & 0.54 & - & 0.45 & - & 0.59 & 0 \\
\hline
\end{tabular}

*WPV: Weeks post vaccination, **A: FMDV serotype A, ***O: FMDV serotype O

The recommended protective levels of FMD antibody titers are $1.9 \log _{10}$ for ELISA for both of type A and O as estimated by ELISA [4]

Table-5. Determine FMD lesions and protection percentage in calves vaccinated with bivalent FMD and $1.5 \mathrm{~mL} / 100 \mathrm{Kg}$ body weight ultra-corn simultaneously after challenge against both types of FMD virus

\begin{tabular}{|c|c|c|c|c|c|c|c|c|c|}
\hline \multirow[t]{3}{*}{ Animals No. } & \multirow[t]{3}{*}{ Treatment of animals } & \multicolumn{7}{|c|}{ Determined FMD lesions } & \multirow[t]{3}{*}{ challenge } \\
\hline & & \multicolumn{3}{|c|}{ Oral lesions } & \multicolumn{2}{|c|}{ Fore limbs } & \multicolumn{2}{|c|}{ Hind limbs } & \\
\hline & & Tongue & Gum & Lip & Left & Right & Left & Right & \\
\hline 1 & vaccinated with FMD & $t^{*}$ & $-* *$ & - & + & - & - & + & A \\
\hline 2 & bivalent oil & + & - & - & - & - & - & - & A \\
\hline 3 & vaccine alone & - & - & - & - & - & - & - & A \\
\hline 4 & & + & - & - & - & - & - & - & A \\
\hline 5 & & - & - & - & - & - & - & - & A \\
\hline 6 & & - & - & - & - & - & - & - & 0 \\
\hline 7 & & + & - & - & - & - & - & - & 0 \\
\hline 8 & & - & - & - & - & - & - & _- & 0 \\
\hline 9 & & - & + & + & + & + & - & + & $\mathrm{O}$ \\
\hline \multirow[t]{2}{*}{10} & & - & - & - & - & - & - & - & 0 \\
\hline & & & & & \multicolumn{2}{|c|}{ Protection $80 \%$} & & & \\
\hline 11 & vaccinated with FMD & + & - & - & - & - & - & - & A \\
\hline 12 & bivalent oil vaccine & - & - & - & - & - & - & - & A \\
\hline 13 & and $1.5 \mathrm{~mL}$ of ultra corn & - & - & - & - & - & - & - & A \\
\hline 14 & simultaneously & + & - & - & - & - & - & - & A \\
\hline 15 & & - & - & - & - & - & - & - & A \\
\hline 16 & & - & - & - & - & - & - & - & $\mathrm{O}$ \\
\hline 17 & & - & - & - & - & - & - & - & $\mathrm{O}$ \\
\hline 18 & & - & - & - & - & - & - & - & 0 \\
\hline 19 & & - & - & - & - & - & - & - & 0 \\
\hline \multirow[t]{2}{*}{20} & & - & - & - & - & - & - & - & $\mathrm{O}$ \\
\hline & & & & & \multicolumn{2}{|c|}{ Protection $100 \%$} & & & \\
\hline 21 & control positive A & + & - & - & + & + & + & - & A \\
\hline 22 & & + & + & + & + & + & - & + & A \\
\hline \multirow[t]{2}{*}{23} & & - & + & + & \multirow{2}{*}{\multicolumn{2}{|c|}{$\begin{array}{l}+ \\
\text { Protection } 0 \%\end{array}$}} & + & + & A \\
\hline & & & & & & & & & \\
\hline 24 & control positive $\mathrm{O}$ & + & + & - & + & - & - & + & 0 \\
\hline 25 & & + & + & + & + & + & + & + & $\mathrm{O}$ \\
\hline \multirow[t]{2}{*}{26} & & + & + & + & - & + & + & + & $\mathrm{O}$ \\
\hline & & & & & \multicolumn{2}{|c|}{ Protection $0 \%$} & & & \\
\hline
\end{tabular}

$*(+)$ : means lesion $\quad * *(-)$ : no lesion 
lesions on tongue epithelial or on buccal mucosa and feet. The lesions vary from erosion, vesicles and ulceration. These signs appear to be characteristic for FMD as stated by $[2,4,12,13,25]$. In the 10 calves vaccinated with FMD oil vaccine alone, one of the five challenged calves with serotype (A) showed generalized infection (means $80 \%$ protection against serotype A), also one of the five challenged calves with serotype (O) showed generalized infection (means $80 \%$ protection against serotype $\mathrm{O}$ ) showing that the protection \% for the FMD oil vaccine alone is $80 \%$. On the other side, all of the 10 calves vaccinated with FMD oil vaccine simultaneously with $1.5 \mathrm{~mL}$ ultra-corn were protected against both types of FMD virus $(\mathrm{A}, \mathrm{O})$, showing a protection $\% 100 \%$.

The present obtained results indicate that 1.5 $\mathrm{mL} / 100 \mathrm{~kg}$ body weight ultra-corn enhances the immune response of vaccinated calves to FMD oil bivalent vaccine and could be used as an immune potentiation to improve the immunogenicity of FMD vaccine and elongate the immune duration.

\section{Conclusion}

As per our results, it is concluded that ultra-corn has a potential effect on the immunogenicity of bivalent oil FMD vaccine providing high immune levels of long duration.

\section{Authors' contribution}

EMM helped in import of ultracorn from company, done serological tests, prepared challenged virus of FMD, drafted the manuscript. EEI implemented the study design, communicate with the company and mailing them to import the material of ultracorn, preparation of bivalent inactivated FMD oil vaccine, done serological tests, prepared challenged virus of FMD, drafted the manuscript, follow up with journal. FSM done serological tests, drafted and revised the manuscript. All authors read and approved the final manuscript.

\section{Acknowledgements}

Authors are thankful to Prof. Dr. Seham Abd ELRashid Director of VSVRI, Prof. Dr. Sayed Zedan Deputy of VSVRI and all members of FMD department specially Prof. Dr. Magdy Abd El-Aty head of FMD department, VSVRI. Also thanks to Prof. Dr. Mohamed Hassan Khoudier, Prof. Dr. Khayrat Abdel Mageed Elian for reviewing this work. This work was funded by Veterinary Serum and Vaccine Research Institute, Abbasia, Cario, Egypt.

\section{Competing interests}

Authors declare that they have no competing interest.

\section{References}

1. Paton, D. J., Sumption, K. J. and Charleston, B., (2009) Options for control of foot and-mouth disease: knowledge, capability and policy. Philos. Trans. R. Soc. B, 364: 2657-2667, http://dx.doi.org/10.1098/rstb.2009.0100.

2. Juleff N. D., Maree, F. F., Waters, R., Bengis, R. G. and
Charleston B. (2012) The importance of FMDV localisation in lymphoid tissue. Veterinary Immunology and Immunopathology, 148:145-148.

3. Franki, R. I. B., Fauquet, C. M., Knudson, D. L. and Brown, F. (1991) Classification and nomenclature of viruses. $5^{\text {th }}$ Report of Int. Comm. on taxonomy of viruses suppl. 2.

4. OIE (2010) Foot and mouth disease, Chapter 2.1.1. In manual of standards for diagnostic tests and vaccine, $4^{\text {th }}$ Ed. Paris, 77-92.

5. Barteling, J. (2002) Development and performance of inactivated vaccines against foot and mouth disease. Rev. Sci.Tech., 21 (3): 577-588.

6. Patil, P. K., Bayry, J., Ramakrishna, C., Hugar, B., Misra, L. D. and Natarajan, C. (2002) Immune response of goats against FMD quadrivalent vaccine: comparison of double oil emulsion and aluminum hydroxide gel vaccine in eliciting immunity, Vaccine, 20: 2781-2789.

7. Gamil, M. A (2010) Studies on the immune response of calves vaccinated against inactivated bivalent FMD virus vaccine type $\mathrm{O} 1$ and A Egypt 2006. M.V.Sc in Veterinary Science (virology). Benha University.

8. Fathia, A. M. (2003) Vaccination of goats with FMD vaccines. MVSc Thesis, University of Alexandria.

9. Sonia, A. M. (2007) Studies on the preparation of an improved Foot and Mouth Disease oil vaccine. Ph. D. Thesis, University of Cairo.

10. Selim, A. M. A., Abouzeid, N. Z., Aggour, A. M. and Sobhy, N. M. (2010) Comparative Study for Immune Efficacy of Two Different Adjuvants Bivalent FMD Vaccines in Sheep. Journal of American Science 6(10):1292-1298.

11. Fadia, S. Hussein, Roushdy, O. H. and Halima, El-Watany (2000) Effect of simultaneous administration of ultra-corn with FMD gel vaccine in calves. J. Egypt Vet. Med. Ass. 60: (4): 81-90.

12. El-Sayed, E., Mossad, W., Ali, S. M. and Shawky, M. (2012): Studies on the duration of immunity induced in cattle after natural FMD infection and post vaccination with bivalent oil vaccine, Vet World, 5(10): 603-608.

13. Huang, Xuan, Yong, Li, Hui, Fang and Congyi, Zheng (2011) Establishment of persistent infection with foot and mouth disease virus in BHK-21 cells. Virology Journal, 8: 169.

14. El-Sayed,E., Wael Mossad Gamal El-Din, Sonia Ahmed Rizk and Magdi Abd El-Aty (2012) Effect of Different Storage Temperatures on the Efficacy of the Bivalent Foot and Mouth Disease Oil Vaccine. Journal of Advanced Veterinary Research, 2:198-205.

15. Ferreira, M. E. V. (1976) Prubade microneutralization poraestudies de anticueropos de la fibre aftosa. $13^{\text {th }}$ Centropanamericano Fiebre Aftosa, (21/22): 17-24.

16. Ferris, N. P., Kitching, R. P., Oxtoby, J. M., Philpot, R.M. and Rendle, R. (1990) Use of inactivated foot-and-mouth disease virus antigen in liquid-phase blocking ELISA. Journal of Virological Methods, 29:33-41.

17. Depa, P. M., Dimri, U., Sharma, M. C. and Tiwari, R. (2012) Update on epidemiology and control of Foot and Mouth Disease - A menace to international trade and global animal enterprise, Vet World, 5(11): 694-704.

18. Jamal, S. M., Ahmed, S., Hussains, M. and Ali, Q., (2008) Status of Foot and Mouth disease in Pakistan. The Global control of FMD - Tools, ideas and ideals - Erice, Italy 14-17 October 2008.

19. Iyer, A.V., Ghosh, S., Singh, S. N. and Deshmukh, R. A. (2001) Evaluation of three ready to formulate oil adjuvants for foot and mouth disease vaccine production. Vaccine, 19(9-10): 1097-1105.

20. Abu Bakr, A. M. A. (2010) Trial for production of bivalent oil adjuvant FMD vaccine. Ph.D. (Virology), Fac. Vet. Med., Alex. University.

21. El-Sayed, E (2011) Advanced studies on Foot and Mouth Disease Vaccines of sheep in Egypt. Ph. D. (Infectious Diseases), Fac. Vet. Med., Cairo University.

22. Helpern, B., Fray, A., Crepin, Y., Platica, O., Lorinet, A.M., 
Rabourdin, A., Sparros, L. and Isac, R. (1973) Corynebacterium parvum, a potent immunostimulant in experimental infectious and in malignancies. In Immunopotentiation. Ciba Foundation symposium No. 18 edited by G.E.W. Wolsten holme and Knight Elsever, Amsterdam pp. 217-236.

23. Frost, P. and Lance, E. M.(1973) The relation of lymphocyte trapping to the mode of action of adjuvants in immunopotentiation. Cida Foundation Symposium No. 18, edited by G.E.W. Walsten holme. J. Knight Elsevier, Amsterdam, pp.
$29-45$.

24. Soliman, R., Reda, I., Youssef, S. A. and Refai, M. (1991) Effect of ultra-corn on chicken immune response to Newcastle disease virus vaccine. J. Egypt. Vet. Med. Ass. 51 (1): 387-400

25. Orsel, K., Bouma, A., Dekker, A., Stegeman, J. A. and de Jong, M. C. M. (2009) Foot and mouth disease virus transmission during the incubation period of the disease in piglets, lambs, calves, and dairy cows. Prev Vet Med. 88(2):158-63.

$* * * * * * * *$ 